\title{
ANALISIS PERHITUNGAN DAN PELAPORAN PAJAK HOTEL DAN RESTORAN PADA HOTEL WHIZ PRIME MANADO
}

\author{
Monica Senduk ${ }^{1}$, David P. E. Saerang ${ }^{2}$, Jenny Morasa ${ }^{3}$ \\ 1,2,3 Jurusan Akuntansi, Fakultas Ekonomi dan Bisnis, Universitas Sam Ratulangi, Jl. Kampus UNSRAT \\ Manado, Indonesia, 95115 \\ E-mail : monica.stefanies@gmail.com
}

\begin{abstract}
As the development of tourism industry in Manado City, make a potential impact for the hotel industry in Manado City. Thus we must pay more attention to the tax treatment in the hospitality business, both in its application and calculation. The purpose of this study was to find out the application of hotel tax accounting at Whiz Prime Hotel Manado. This type of research is descriptive. Data obtained through field observations, interviews and library research. Data were then analyzed using qualitative descriptive analysis methods. The results showed that the calculation and deduction of local taxes on Whiz Prime Hotel Manado already refers to existing tax regulations. Hotel tax calculation in every transaction is done at the end of every month by Whiz Prime Hotel. Although the application and calculation have been implemented according to the existing regulations, but there are still those who do not understand what supporting services are in hotel taxes. For this reason, Whiz Prime Hotel is expected to maintain existing performance and improve understanding and application, so that services and human resources can be better.
\end{abstract}

Keywords: hotel taxes; tax accounting; analysis.

\section{PENDAHULUAN}

Demi meningkatkan kemampuan keuangan daerah sehingga bisa melaksanakan otonomi yang khususnya berasal dari pajak daerah dan retribusi daerah, oleh sebab itu pemerintah menetapkan berbagai kebijakan perpajakan daerah, diantaranya dengan menetapkan Undang-Undang (UU) Nomor 28 Tahun 2009 tentang Pajak Daerah dan Retribusi Daerah sebagaimana telah diubah beberapa kali atas UU No. 34 Tahun 2000 dan UU No. 18 Tahun 1997.

Pengenaan Pajak Hotel tidak mutlak berlaku pada seluruh daerah kabupaten atau kota yang ada di Indonesia. Hal ini berhubungan dengan kewenangan yang diberikan kepada pemerintah kabupaten atau kota untuk mengenakan atau tidak mengenakan suatu jenis pajak kabupaten/kota. Oleh karena itu, untuk dapat dipungut pada suatu daerah kabupaten atau kota, pemerintah daerah harus terlebih dahulu mengambil kebijakan dengan menerbitkan peraturan daerah tentang Pajak Hotel.

Peraturan itu yang akan menjadi landasan hukum dalam pelaksanaan pengenaan dan pemungutan Pajak Hotel di daerah kabupaten atau kota yang bersangkutan. Sesuai dengan pasal 1 angka 8 Peraturan Daerah Kota Manado Nomor 2 Tahun 2011 menyebutkan "Pajak Daerah yang selanjutnya disebut Pajak adalah kontribusi wajib kepada Daerah yang terutang oleh Orang pribadi atau badan yang bersifat memaksa berdasarkan UU, dengan tidak mendapatkan imbalan secara langsung dan digunakan untuk keperluan daerah bagi sebesarbesarnya kemakmuran rakyat". Pasal 1 angka 10 menyebutkan bahwa "Pajak Hotel adalah pajak atas pelayanan yang disediakan oleh hotel", dan pasal 1 angka 12 menyebutkan bahwa "Pajak Restoran adalah pajak atas pelayanan yang disediakan oleh restoran". 


\section{TINJAUAN PUSTAKA}

Menurut Ismail (2010:2), akuntansi dapat diartikan sebagai seni dalam melakukan pencatatan, penggolongan, dan pengikhtisaran yang mana hasil akhirnya tercipta sebuah informasi seluruh aktivitas kuangan perusahaan. Sedangkan menurut Weygandt et al. (2011) menyatakan bahwa: "accounting purpose to identify, record, and communicate the economics events of an organization to interested users".

Prasetyono (2011:13) menyatakan bahwa, "pajak adalah iuran rakyat kepada kas negara berdasarkan Undang-Undang, sebagai perwujudan pengabdian dan peran serta rakyat untuk membiayai negara dan pembangunan nasional". Menurut Sari (2013:37), terdapat dua macam fungsi pajak, yaitu:

1. Fungsi Penerimaan (Budgetair). Fungsi penerimaan merupakan alat atau sumber untuk memasukan uang sebanyak-banyaknya dalam kas Negara yang bertujuan untuk membiayai pengeluaran Negara baik untuk pengeluaran rutin maupun pembangunan. Pajak sebagai sumber pendapatan Negara berfungsi untuk membiayai pengeluaranpengeluaran Negara. Demi melancarkan tugas rutin maupun pembagunan maka Negara membutuhkan biaya. Penerimaan pajak merupakan sumber biaya yang diperoleh Negara. Pajak dimanfaatkan guna untuk pembiayaan rutin seperti pembelanjaan, pemeliharaan dan sebagainya. Sedangkan untuk pembiayaan pembangunan uang yang dikeluarkan berasal dari tabungan pemerintah yaitu penerimaan dalam negeri yang dikurangi pengeluaran rutin. Peningkatan tabungan pemerintah terus diharapkan setiap tahunnya sesuai dengan kebutuhan pembiayaan pembangunan yang semakin meningkat dan ini terus diharapkan dari sektor pajak.

2. Fungsi Mengatur (Regulerend). Fungsi mengatur merupakan alat guna mencapai berbagai tujuan di bidang keuangan, misalnya untuk mengadakan perubahan tarif, memberikan pengecualian dan keringanan-keringanan begitupun sebaliknya untuk pemberatanpemberatan terhadap masalah tertentu. Pemerintah bisa mengatur pertumbuhan ekonomi melalui kebijaksanaan pajak. Sesuai fungsinya yang mengatur, pajak dapat digunakan sebagai alat untuk mencapai tujuan. Pelaksanaan fungsi ini bisa positif maupun negatif. Yang dimaksud dengan fungsi pajak positif adalah jika suatu kegiatan yang dilakukan masyarakat dipandang sebagai sesuatu yang positif oleh pemerintah, oleh sebab itu pemerintah memberikan dorongan berupa insentif pajak yang dilakukan dengan cara pemberian fasilitas pajak. Dan pelaksanaan fungsi mengatur yang bersifat negatif dimaksudkan untuk mencegah atau menghalangi perkembangan yang menjuruskan kehidupan masyarakat ke arah tujuan tertentu. Hal itu dapat dilakukan dengan membuat peraturan di bidang perpajakan yang menghambat dan memberatkan masyarakat untuk melakukan suatu kegiatan yang ingin diberantas oleh pemerintah.

Menurut Waluyo (2014:12), pajak digolongkan dalam beberapa jenis dimana seluruhnya sangat berperan bagi pembangunan nasional. Pengelompokkan itu antara lain didasarkan pada pajak menurut golongan, lembaga pemungut, dan sifatnya. Sumarsan (2012:7) menjelaskan bahwa pemungutan Pajak dilaksanakan dengan menggunakan tiga sistem sebagai berikut: (a) official assesment system; (b) self assesment system; dan (c) withholding system. Menurut Undang-Undang Nomor 28 Tahun 2009, Pajak Hotel adalah pajak atas pelayanan yang disediakan oleh hotel. Hotel adalah fasilitas penyedia jasa penginapan peristirahatan termasuk jasa terkait lainnya dengan dipungut bayaran, yang mencakup juga motel, losmen, gubuk pariwisata, wisma pariwisata, pesanggrahan, rumah penginapan dan sejenisnya, serta rumah kos dengan jumlah kamar lebih dari 10 (sepuluh).

Pasulu dan Wokas (2015), menyimpulkan pemungutan/penerimaan pajak restoran dan pajak hotel di Dinas Pendapatan Daerah Kota Bitung selama 5 (lima) tahun terakhir sejak tahun 2010 hingga tahun 2014 mengalami peningkatan setip tahunnya hal ini disebabkan karena adanya peningkatan kesadaran dari setiap wajib pajak. Serta mekanisme perhitungan 
pajak restoran dan pajak hotel di dinas pendapatan daerah kota bitung yaitu pajak dihitung sendiri oleh wajib pajak. Muhaling, et al. (2017), menyatakan perhitungan dan pencatatan PPh Pasal 21 untuk para pensiun yang telah dilakukan oleh PT. Taspen (Persero) Cabang Manado pada saat terjadinya transaksi yang berkaitan telah memadai. Dan PT. Taspen (Persero) Cabang Manado selalu mengantisipasi untuk membayar atau melaporkan PPh Pasal 21 yang terutang lebih cepat apabila tanggal pelaporan dan penyetoran tersebut jatuh pada hari libur atau tanggal merah, maka tanggal pelaporan dan penyetoran dapat digeser pada hari kerja agar PT. Taspen (Persero) Cabang Manado terhindar dari sanksi pajak.

Tamalanga dan Sabijono (2019) menyimpulkan bahwa Hotel Wisma Nusantara Tondano telah memahami dan menerapkan konsep pengakuan, pengukuran, dan pengungkapan pendapatan berdasarkan Standar Akuntansi Keuangan untuk Entitas Tanpa Akuntabilitas Publik dengan baik. Serta metode pengakuan pendapatan Hotel Wisma Nusantara Tondano berdasarkan metode accrual basic, yaitu pendapatan diakui saat terjadinya transaksi penyewaan kamar hotel. Menurut Putri, et al. (2018), faktor yang mempengaruhi penerimaan pajak hotel pada periode 2010 sampai dengan periode 2016, yaitu jumlah hotel dan jumlah penduduk yang ada di Kabupaten Kotawaringin timur, yang mengindikasikan bahwa semakin banyak jumlah penduduk maupun jumlah hotel maka akan meningkatkan penerimaan pajak hotel yang akan berpengaruh terhadap Pendapatan Asli Daerah.

\section{METODE PENELITIAN}

Jenis penelitian ini adalah deskriptif. Menurut Sedarmayanti dan Hidayat (2011), "penelitian deskriptif merupakan metode penelitian yang digunakan untuk menemukan pengetahuan yang seluas-luasnya terhadap objek penelitian pada suatu masa tertentu". Penelitian ini dilakukan di Hotel Whiz Prime Manado dengan alamat Jl. Piere Tendean Boulevard, Manado, Kota Manado, Sulawesi Utara 95111. Langkah-langkah prosedur penelitian yang digunakan adalah:

1. Mendefinisikan dan merumuskan masalah yang ditemui untuk kemudian dapat diteliti dan dicari solusinya.

2. Pengumpulan informasi dengan mencari berbagai literature dari berbagai sumber.

3. Mencari data secara langsung yang dipeoleh dari Hotel Whiz Prime Manado.

4. Melakukan penelitian dan pembahasan berdasarkan data yang telah didapatkan sebelumnya dan mengkaji kembali apakah sesuai dengan teori-teori yang telah ada.

5. Menarik kesimpulan serta memberikan saran dari penulis sesuai dengan hasil penelitian dan pembahasan, apakah permasalahan yang telah dibahas tersebut memiliki dampak bagi perusahaan itu sendiri.

Metode yang digunakan untuk menganalisis data adalah metode deskriptif kualitatif. Seperti yang dikemukakan oleh Mohammad (2011:186), metode deskriptif adalah suatu metode yang digunakan untuk meneliti status sekelompok manusia, suatu objek, suatu set kondisi, suatu sistem pemikiran, ataupun suatu kelas peristiwa pada masa sekarang. Sedangkan menurut Moleong (2011:4), metode kualitatif sebagai prosedur penelitian yang menghasilkan data deskriptif berupa kata-kata tertulis atau lisan dari orang-orang dan perilaku yang diamati. Data yang dihasilkan berupa kata-kata, gambar serta perilaku manusia. Sukmadinata (2011:73), menyatakan penelitian deskriptif kualitatif ditujukan untuk mendeskripsikan dan menggambarkan fenomena-fenomena yang ada, baik bersifat alamiah maupun rekayasa manusia, yang lebih memperhatikan karakteristik, kualitas, dan keterkaitan antar kegiatan. 


\section{HASIL PENELITIAN DAN PEMBAHASAN}

\subsection{Hasil penelitian}

Hotel Whiz Prime Manado merupakan bagian dari Intiwhiz Hospitality Management. Intiwhiz Hospitality Management adalah jaringan hotel manajemen sejak tahun 2008 yang merupakan salah satu anak perusahaan dari PT. Intiland Development Tbk yang bergerak di bisnis perhotelan dengan visi untuk menjadi jaringan hotel yang paling diminati dan bertumbuh pesat di Indonesia yang didukung dengan sistem pemasaran, reservasi dan operasional kepada seluruh Hotel jaringan Intiwhiz International.

Intiwhiz Hospitality Management memulai operasional pada tahun 2010 dengan mempunyai empat Brand yaitu Whiz Capsule, Whiz Hotel, Whiz Prime, Grand Whiz, dan Hotel Managed By Swift Inn Aeroplis Airport Jakarta. Berdasarkan klasifikasi bintang, Grand Whiz masuk dalam Kategori brand hotel bintang empat yang mengedepankan kemewahan modern dengan ruang bernuansa alam yang memiliki ciri khas simple, Whiz Prime untuk Kategori brand hotel bintang tiga dengan konsep dinamis hotel, sedangkan Whiz Hotel, Whiz Capsule Hotel dan Swift Inn Aeropolis Airport Jakarta untuk Kategori brand hotel bintang dua yang mengedepankan simple dinamis dan smart hotel. Hotel Whiz Prime Manado sendiri berdiri dibawah perusahaan PT. Milenia Megamas. Hotel Whiz Prime Manado resmi dibuka dan beroperasi sejak tanggal 11 November tahun 2016 dan diresmikan oleh Cosmas Batubara sebagai Wakil Komisaris Independen Tunas Group.

Perhitungan Pajak Hotel di Hotel Whiz Prime Megamas Manado. Berdasarkan hasil penelitian ditemukan bahwa pendapatan Hotel Whiz Prime Megamas Manado untuk periode Mei 2019-Juli 2019 dikenakan potongan pajak sebesar 10\% sesuai dengan peraturan daerah yang ada, jadi dari total yang ada akan dikalikan dengan 10\%, maka hasil perkalian tersebut itulah keuntungan bersih yang diterima hotel. Sesuai Peraturan Daerah Kota Manado No. 2 Tahun 2011 tentang Pajak Daerah yang menentukan tarif Pajak Hotel ditetapkan sebesar 10\% (sepuluh persen). Dari data yang ada, Hotel Whiz Prime Megamas Manado juga menerapkan potongan pajak hotel sebesar $10 \%$. Berikut merupakan potongan pajak hotel dari transaksi pada periode Mei 2019 hingga Juli 2019.

$$
\begin{aligned}
\text { Pajak terutang Mei } 2019 & =\text { Tarif Pajak Hotel (10\%) x Dasar Pengenaan Pajak } \\
& =10 \% \times \text { Rp. } 1,691,723,271 \\
& =\text { Rp. } 169,172,327
\end{aligned}
$$

Dapat dilihat dari data di atas bahwa total penjualan setelah dikurangi pajak hotel maka laba bersih yang diterima pihak hotel pada bulan Mei 2019 adalah sebesar Rp.1,522,550,944.

Pajak terutang Juni $2019=$ Tarif Pajak Hotel $(10 \%) \times$ Dasar Pengenaan Pajak

$$
=10 \% \times \text { Rp. } 1,703,307,872
$$

$=$ Rp. $170,330,787$

Dapat dilihat dari data di atas bahwa total penjualan setelah dikurangi pajak hotel maka laba bersih yang diterima pihak hotel pada bulan Juni 2019 adalah sebesar Rp.1,532,977,085.

Pajak terutang 2019

$$
\begin{aligned}
& =\text { Tarif Pajak Hotel }(10 \%) \times \text { Dasar Pengenaan Pajak } \\
& =10 \% \text { x R. } 2,034,028,833 \\
& =\text { Rp. } 203,402,883
\end{aligned}
$$

Dapat dilihat dari data di atas bahwa total penjualan setelah dikurangi pajak hotel maka laba bersih yang diterima pihak hotel adalah sebesar Rp.1,830,625,950.

Perhitungan Pajak Restoran di Hotel Whiz Prime Megamas Manado. Berdasarkan hasil penelitian ditemukan bahwa pendapatan Restoran Napoleon di Hotel Whiz Prime Megamas Manado periode Mei 2019 hingga Juli 2019 dikenakan potongan pajak sebesar $10 \%$ sesuai dengan peraturan daerah yang ada, jadi dari total yang ada akan dikalikan dengan $10 \%$, maka hasil perkalian tersebut itulah keuntungan bersih yang diterima Restoran Napoleon di Hotel Whiz Prime. Sesuai Peraturan Daerah Kota Manado No. 2 Tahun 2011 tentang Pajak Daerah yang menentukan tarif Pajak Restoran ditetapkan sebesar 10\% (sepuluh 
persen). Dari data yang ada, Restoran Napoleon di Hotel Whiz Prime Megamas Manado juga menerapkan potongan pajak hotel sebesar $10 \%$. Berikut merupakan potongan pajak restoran dari transaksi periode Mei 2019 hingga Juli 2019.

Pajak terutang Mei $2019=$ Tarif Pajak Restoran (10\%) $\times$ Dasar Pengenaan Pajak

$=10 \% \times$ Rp. $204,113,174$

$=\mathrm{Rp} \cdot \operatorname{Rp} 20,411,317$

Dapat dilihat dari data di atas bahwa total penjualan setelah dikurangi pajak restoran maka laba bersih yang diterima pihak restoran pada bulan Mei 2019 adalah sebesar Rp.183,701,857.

Pajak terutang Juni $2019=$ Tarif Pajak Restoran (10\%) $\times$ Dasar Pengenaan Pajak

$=10 \% \times$ Rp. $202,651,011$

$=$ Rp. 20,265,101

Dapat dilihat dari data di atas bahwa total penjualan setelah dikurangi pajak restoran maka laba bersih yang diterima pihak restoran pada bulan Juni 2019 adalah sebesar Rp.182,385,910 Pajak terutang Juli $2019=$ Tarif Pajak Restoran (10\%) $\times$ Dasar Pengenaan Pajak

$=10 \% \times$ Rp. $226,806,749$

$=$ Rp. $22,680,674$

Dapat dilihat dari data di atas bahwa total penjualan setelah dikurangi pajak restoran maka laba bersih yang diterima pihak restoran adalah sebesar Rp. 204,126,075

\subsection{Pembahasan}

Berdasarkan hasil analisis sebelumnya ditemukan bahwa perhitungan pajak hotel dan pajak restoran yang diterapkan di Hotel Whiz Prime Megamas Manado sudah sesuai dengan yang telah di tetapkan oleh pemerintah. Hal ini terlihat dari perhitungan pajak hotel Whiz Prime Megamas Manado dari bulan Mei 2019 - Juli 2019 yang sudah menerapkan pajak hotel sebesar $10 \%$ dan pajak restoran sebesar 10\%, sehingga dapat di simpulkan bahwa perhitungan pajak yang diterapkan oleh pihak Hotel Whiz Prime Megamas Manado sudah sesuai dengan Peraturan Daerah kota Manado tentang Pajak Daerah dan tidak di temukan kekeliruan dalam perhitungannya.

Adapun pelaporan pajak hotel dan restoran yang dilakukan sudah baik, karena setelah hotel menerima pembayaran dari tamu, maka nilai yang dibayarkan akan tersimpan ke dalam pelaporan harian Surat Pemberitahuan Pajak Daerah. Jika transaksi harian mencapai akhir bulan maka. Pada bulan berikutnya wajib pajak harus melakukan pembayaran pajaknya melalui formulir Surat Setoran Pajak Daerah. Selanjutnya menyetorkan uang pajak hotel bersamaan dengan pajak restoran ke kas pemerintah dan akan di berikan surat tanda terima setoran atau Surat Tanda Terima Setoran sebagai bukti pembayaran dan pengawasan.

\section{KESIMPULAN DAN SARAN}

\subsection{Kesimpulan}

Hasil analisis menyimpulkan bahwa perhitungan pajak hotel dan pajak restoran yang di terapkan oleh Hotel Whiz Prime Megamas Manado sudah sesuai dengan Peraturan Daerah Kota Manado tentang Pajak Daerah, serta tidak ditemukan kekeliruan yang terjadi dalam perhitungan pajak yang dilakukan oleh pihak hotel dan Pelaporan yang dilakukan pun terkait pajak hotel dan restoran sudah baik.

\subsection{Saran}

Untuk Hotel Whiz Prime Megamas Manado untuk mempertahankan perhitungan pajak yang telah diterapkan, sehingga dalam penyetoran pajak ke Badan Pengelolan Pajak dan Retribusi Daerah tidak terjadi masalah dan dapat berjalan dengan baik. 


\section{DAFTAR PUSTAKA}

Ismail. (2010). Manajemen perbankan, Edisi Pertama. Jakarta: Kencana.

Mohammad, N. (2011). Metode penelitian. Jakarta: Ghalia Indonesia.

Moleong, L. J. (2011). Metodologi penelitian kualitatif, Edisi Revisi. Bandung: PT Remaja Rosdakarya.

Muhaling, O. M., Tinangon, J. J., \& Budiarso, N. B. (2017). Analisis perhitungan dan pelaporan pajak penghasilan pada PT. Taspen (Persero) Cabang Manado. Jurnal EMBA: Jurnal Riset Ekonomi, Manajemen, Bisnis dan Akuntansi, 5(1), 57-67. https://ejournal.unsrat.ac.id/index.php/emba/article/view/15423

Pasulu, S. R., \& Wokas, H. R. N. (2014). Analisis perhitungan dan pemungutan pajak restoran dan pajak hotel di Dinas Pendapatan Daerah Kota Bitung. Jurnal EMBA: Jurnal Riset Ekonomi, Manajemen, Bisnis dan Akuntansi, 3(2), 1008-1015. https://ejournal.unsrat.ac.id/index.php/emba/article/view/9279

Peraturan Daerah Kota Manado Nomor 2 Tahun 2011 tentang Pajak Daerah.

Prasetyono, S. (2011). Panduan lengkap tatacara perhitungan Pajak Penghasilan dan Petunjuk Pengisian SPT. Jakarta: Penerbit Laksana.

Putri, N. D., Zuhroh, I., \& Kusuma, H. (2018). Analisis pajak hotel di Kabupaten Kotawaringin Timur. Jurnal Ilmu Ekonomi, 2(2), 346-356. http://ejournal.umm.ac.id/index.php/jie/article/view/7039

Sedarmayanti \& Hidayat, S. (2011). Metodologi penelitian. Bandung: Mandar Maju.

Sari, D. (2013). Konsep dasar perpajakan. Bandung: PT Refika Aditama.

Sukmadinata, N. S. (2011). Metode penelitian pendidikan. Bandung: PT Remaja Rosdakarya.

Sumarsan, T. (2012). Perpajakan Indonesia, Edisi ketiga. Jakarta: Penerbit Indeks.

Tamalanga, S. K., \& Sabijono, H. (2019). Analisis pengakuan, pengukuran dan pengungkapan pendapatan di Hotel Wisma Nusantara Tondano. Jurnal EMBA: Jurnal Riset Ekonomi, Manajemen, Bisnis dan Akuntansi, 7(4), 4475-4483. https://ejournal.unsrat.ac.id/index.php/emba/article/view/25239

Undang-Undang Nomor 28 Tahun 2009 tentang Pajak Daerah dan Retribusi Daerah sebagaimana telah diubah beberapa kali atas Undang-Undang Nomor 34 Tahun 2000 dan Undang-Undang Nomor 18 Tahun 1997.

Waluyo. (2014). Perpajakan Indonesia. Jakarta: Salemba Empat.

Weygandt, J. J., Kimmel, P. D., \& Kieso, D. E. (2011). Financial Accounting, IFRS Edition. United States: John Wiley \& Sons. 